\title{
EVALUATION OF ORGANIZATIONAL CITIZENSHIP BEHAVIOR IN THE CONTEXT OF ORGANIZATIONAL COMMITMENT: THE CASE OF HEFEI PUBLIC SERVICE INSTITUTIONS, CHINA
}

\author{
Sadiq \\ $\mathrm{PhD}$ (in Public Administration), Associate Professor, Research \\ Supervisor in School of Economics and Management \\ Neijiang Normal University-China. \\ Address: Neijiang Normal University, 705 Dongtong road, \\ 641000 Neijiang City, Sichuan Province, China. \\ E-mail: sadiq@njtc.edu.cn

\section{Muhammad Salman Ahmad} \\ (Corresponding author) \\ $\mathrm{PhD}$ (in Public Administration), Associate Professor, Research \\ Supervisor in School of Political Science \& Public Administration \\ Neijiang Normal University-China. \\ Address: Neijiang Normal University, 705 Dongtong road, \\ 641000 Neijiang City, Sichuan Province, China. \\ E-mail: salman@njtc.edu.cn
}

\begin{abstract}
The subject of research is organizational citizenship behavior (OCB) in the context of organizational commitment (OC) in public service institutions of Hefei city, China.

Two research hypotheses have been proposed: "Organizational citizenship behavior has positive relationship with organizational commitment" and "Organizational commitment is a predictor of organizational citizenship behavior". To find the relationship between organizational citizenship behavior and organizational commitment, this study adopted a relational approach. A validated questionnaire from previous studies was used to collect the data. A total of 234 people (78\% response rate) working in different public service institutions responded to the survey. Correlation and regression were used to assess the impact and relationship between variables of this study. The regression and correlation results for this study showed that there is a very strong and significant relationship between the two variables (OCB and OC) in public service institutions of Hefei city. Thus, the results of this study clearly support the idea that policy makers in public service institutions should pay more attention to shaping organizational civic behavior by investing in organizational commitment.
\end{abstract}



havior.

Keywords: public service institutions; organizational commitment; citizenship be-

Citation: Sadiq \& M. Salman Ahmad (2020). Evaluation of Organizational Citizenship Behavior in the Context of Organizational Commitment: The Case of Hefei Public Service Institutions, China. Public Administration Issues, no 6 (Special Issue II, electronic edition), pp. 51-66 (in English), DOI: 10.17323/1999-5431-2020-0-6-51-66.

\section{Introduction}

In recent years, numerous scholarly debates and studies evolving around employee performance and behavior inside organizations have been based upon the concept of organizational citizenship behavior (OCB). Organizational citizenship behavior can be defined as the extendibility of simple behaviors inside an organization (co-workers and supervisors) and outside an organization (clients) (Meynhardt, Brieger \& Hermann, 2020; Organ, 1988). Examples of such behaviors could be helping colleagues in their work, putting extra energy and taking innovative approaches in fulfilling one's own duties, or dealing with clients in the best possible interest of an organization. Many scholars agree that organizational citizenship behavior solved the year's long dilemma of organizational effectiveness. As it is well established that employee attitude, emotions and behaviors at work, together with their beliefs, are highly affected by the way an employee behaves (Jung, Park \& Yoon, 2010), organizational citizenship behavior is in the spotlight of this model. According to Kim (2006), if employee interaction with co-workers and clients shows a positive association and relationship with OCB, the organizational operations will be carried out with a high level of productivity and efficiency, and organizational services can be delivered in the most effective way. However, this dilemma is not adequately studied and examined, especially in the context of public service institutions in China, and most importantly in a third tier city like Hefei (in China). This study is an attempt to bridge that knowledge gap.

There are not enough studies to evaluate organizational citizenship behavior in different cultural contexts (Chen, Tsui \& Farh, 2002; Farh, Zhong \& Organ, 2004; Hui, Law \& Chen, 1999; Khan, Ismail, Hussain \& Alghazali, 2020). It is hard to evaluate and compare the concept of organizational citizenship behavior in Western countries with Chinese public sector organizations because of the communist legacy these organizations are carrying (Farh et al., 2004). According to Cun (2012) there is no adequate literature on applying the theories of private sector organizations to public sector institutions, especially in the context of China because of its unique cultural background characterized by rule, emotion and principle. Further research is needed on OCB in Chinese public sector institutions because most of the employee activities associated with OCB are the results of state promotion (Farh et al., 2004). According to Chen and Francesco (2000) and Chen et al., (2002), Chinese employee behavior is different from that in Western countries in terms of organizational commitment because of China's unique cultural context and further studies are needed to evaluate it properly. 
The basic aim of this study is to elaborate the dimensional factors of organizational citizenship behavior and organizational commitment prevailing in Chinese public service intuitions. There is still a significant research gap and research potential in OCB and OC in order to highlight the predictors of efficiency and effectiveness in Chinese public service intuitions. This study is divided into five sections. The first section highlights the introduction and motivation for this research. The second highlights the literature review and hypothesis development. The third highlights the research methodology. The fourth presents the results and discussion. The last section presents the conclusion, implications and limitations of the study.

\section{Literature review}

To promote the culture of openness, empowerment, mutual trust and collaboration, responsibility and mutual benefit among employees, organizations are encouraged to follow and implement organizational citizenship behavior strategies. Many scholars and researchers examined the practical and theoretical implications of OCB and OC (Kim, 2006; Motalebi \& Marşap, 2020; Motowidlo, 2000; Organ \& Ryan, 1995). According to Muchinsky (2007), employee commitment is the employees' predisposed loyalty to their employer. When employees and an organization endeavor to have a mutually beneficial relationship then organizational commitment will emerge (Chen et al., 2002; Davenport, 1999; Lambert, Keena, Leone, May \& Haynes, 2020). According to Mathieu and Zajac (1990), all theories and definitions of organizational commitment have one thing in common, that is, an emotional link between organization and individuals. The loyalty an employee is experiencing with the organization creates a bond between them and this loyalty-based bond keeps the employee motivated to work with that organization. Organizational commitment is a kind of emotional attachment of an employee with his job or organization (Cohen, 2017; Newstrom \& Davis, 1986).

According to Karim and Noor (2017) and the model posited by Meyer \& Allen (1991), organizational commitment has three dimensions: moral commitment, affective commitment, and necessary commitment. Moral commitment is a kind of commitment that an employee feels through wanting to stay in the organization. Affective commitment is the emotional attachment employees feel towards an organization. Affective commitment is the sense of satisfaction employees get by working in a particular organization; which also minimizes the chances of job turnover. Employees experiencing affective commitment think the particular organization they are working with is the right organization for them. Necessary commitment is the mutual tradeoff between an organization and an employee. Necessary commitment is associated with the cost the employee will bear if he leaves the organization and the investment in time, labor, and effort the employee made in that particular organization to reach a certain level. The employee understands and fears losing that certain level and benefits associated with that level if he leaves the organization. Affective commitment and normative commitment are both part of organizational citizenship behavior. Any employee who has a high degree 
of moral commitment will likely serve the organization with a high degree of loyalty, and will be likely to impose responsibilities and obligations on colleagues.

According to Meyer and Allen (1991) the reason behind any individual acting to create a positive environment in an organization are their feelings for that particular organization, which motivate him to do so. That is why moral commitment is always associated with high performance, good behavior, punctuality, and traits of organizational citizenship behavior (Karim \& Noor, 2017). Individuals who demonstrate normative commitment are loyal to their particular institutions. They integrate the organization's values and culture into their own values and culture, and they think of their job as a noble cause. To them being a part of their particular organization is the right thing to do, sharing and supporting organizational culture and values they identify with.

Most of the studies conducted after 1990 used the three dimensional conceptual model of organizational commitment proposed by Allen and Meyer (1990). According to Meyer (1997), only those employees who are engaged will likely remain in the organizations compared to those employees who are not. We can say that organizational commitment is an emotional bond between an employee and his job. Becker (1960) stated that organizational commitment is the result of an individual decision, to go along with his job for the long-term benefits (retirement and pension plans) the individual is getting from that particular organization. Leaving the organization means leaving all these long-term benefits.

Podsakoff, MacKenzie, Paine and Bachrach (2000) in their study reviewed the literature and examined the background and work of other scholars on this subject. The three dimensional model which was proposed by Allen and Meyer (1990) in their study consists of normative commitment, affective commitment, and continuance commitment. They described normative commitment as obligatory commitment, affective commitment as value based commitment, and continuance commitment as cost and benefit commitment. They stated that these dimensions of organizational commitment work differently for different variables, working as antecedents or consequences (Karim \& Noor, 2017; Meyer \& Allen, 1991; Rifai, 2005).

In a study by Meyer, Becker and Vandenberghe (2004), organizational commitment is linked to employee motivation. It is evident that employee engagement can be observed by their actions and behavior inside the organization, for instance, their willingness to work longer hours (Hallberg \& Schaufeli, 2006). This supports the idea of strengthening the various prospects of organizational citizenship behavior by organizational engagement.

In a study conducted by Gautam, Van Dick, Wagner, Upadhyay and Davis (2005) in Nepalese organizations on the association between OCB and OC, the results indicated a positive and significant association between OCB and OC. In another study by Williams and Anderson (1991) on OC, job satisfaction, OCB, and in-role behavior, the results indicated that organizational commitment, organizational identity, and some aspects of organizational citizenship behavior can be improved through internal communication within an organization.

Other researchers and scholars linked traits of organizational citizenship behavior with organizational commitment in their studies (Bogler \& Somech, 2004; 
Ensher, Grant-Vallone \& Donaldson, 2001; Moorman, Niehoff \& Organ, 1993; Motalebi \& Marşap, 2020; Nguni, Sleegers \& Denessen, 2006; Osborne \& Gaebler, 1993). A study by Zayas-Ortiz, Rosario, Marquez and Colón Gruñeiro (2015) indicated a significant and positive correlation between organizational citizenship behavior and organizational commitment. Based on the above review of literature the following hypothesis has been proposed for reaffirmation:

\section{H1. Organizational citizenship behavior has a positive relationship with organi- zational commitment}

According to Yen and Niehoff (2004), organizational commitment is the only predictor variable which truly explains organizational citizenship behavior actions. Wasti (2003) stated that organizational commitment is an emotional link between employee and organization, promoting employee's OCB in the best interests of an organization. Organizational commitment that results in OCB is the most valuable kind of commitment for any organization. Among the types of commitment, necessary commitment is the least desirable commitment for any organization, because it is based on the economic benefits the organization is offering to its employees, and only exists when the offered economic benefits are comparatively better than other organizations (Clugston, Howell \& Dorfman, 2000; Shin, Park \& Park, 2019).

The best predictor of employee performance and the foremost contributor to organizational human resource which mobilize organizational citizenship behavior is organizational commitment (Zayas-Ortiz et al., 2015). Organizational citizenship behavior is positively related with employee organizational commitment (Yen \& Niehoff, 2004). A significant predictor in employee organizational citizenship behavior is affective organizational commitment (Donglong, Taejun, Julie \& Sanghun, 2020; Nguni et al., 2006; Rifai, 2005). Affective organizational commitment will also result in extra efforts by the employees to increase their behavioral roles inside organizations. Many researchers and scholars, such as T. E. Becker (1992) and Moorman et al. (1993), supported and predicted the correlation between OCB and OC. Wagner and Rush (2000) stated that there is a positive and significant association between altruistic OCB and OC. Bogler and Somech (2004) suggested a positive perception about the correlation between OCB and OC among teachers. Research suggests a positive association between perceptual organizational citizenship behavior and perceptual organizational commitment among teachers (Loi, Hang-Yue \& Foley, 2006; Nguni et al., 2006).

Some scholars in their research on organizational commitment stated a strong and positive relationship between organizational citizenship behavior and normative and affective commitment, whereas continuous commitment has an inverse and negative relationship with organizational commitment and other organizational outcomes such as performance (Shore \& Wayne, 1993). A study by Chen and Francesco (2000) suggested that there is a positive correlation between affective commitment, in-role performance, and $\mathrm{OCB}$, but continuance commitment has a negative and inverse relationship with in-role performance and organizational commitment. There was a strong relationship between inrole organizational citizenship behavior and affective commitment for those em- 
ployees having the lower normative commitment. Gautam et al. (2005) reported a strong and positive relationship between some of the organizational citizenship behavior factors (compliance and altruism) and normative and affective commitment. Human resource managers inside organizations have to use organizational commitment as a tool to build the relationship and link between employee individuality and loyalty with their institutions and institutional goals. This will help organizations to find the most loyal and attached employees, with the prospect of keeping them.

Organ (1988) and Bodla, Tang, Van Dick and Mir (2019) Stated that OCB is a type of behavior which is not a part of employees' formal job descriptions; these include all those explicit behaviors by employees that are not rewarded by the organization. Organ $(1988,1997)$ divided organizational citizenship behavior into five categories and dimensions; civic virtue is the active participation in events organized by the employee organization, e.g., taking part in some social and charitable activities organized by his organization; courtesy is the attitude, respect, and consideration for other people in the workplace; altruism is the employee spirit of volunteering for any problem and work around his workplace; awareness is the employees' optimal behavior and knowhow of the rules, regulations, and procedures of the organization; and "chivalry" is the courage, attitude, and tolerance of an employee around his workplace to avoid problems and complaints.

Most researchers and scholars investigated the idea of organizational citizenship behavior because it is crucial for the effectiveness of an organization (Karim \& Noor, 2017; Meyer, 1997). Institutions will be likely to hire those people having the right skills and qualities prerequisite in the working groups, and who show traits of organizational citizenship behavior. Likewise Smith, Organ and Near (1983) stated that organizations are likely to benefit from hiring employees who show the traits of organizational citizenship behavior. According to Organ (1988) OCB is a way to maintain and retain the human capital inside organizations, and the effects of OCB on different organizational outcomes like innovation, efficiency, and others have already been established. Based on the above literature, the following hypothesis has been proposed for reaffirmation:

\section{H2: Organizational commitment is a predictor of organizational citizenship behavior.}

According to Pattanayak (2020) and Huselid (1995), organizational success depends upon human resource management. It is the duty of human resource management to work and think in the best interests of the organization within set boundaries to achieve organizational goals and objectives. Literature suggests and supports the idea that to create a work environment that is beneficial, motivating, and pleasant, employees need to get along with each other, support each other, work together, respect each other, and understand each other. A work environment based upon the mutual relationship between organizations and their employees will result in achieving organizational and individual goals and objectives. Organizations should pay attention to both productivity factors and the qualityof-life that employees have in their respective organizations. 


\section{Methodology}

Data was collected through a cross sectional study from employees working in public service institutions around Hefei city. A sample of 300 was derived from a population consistent with the Barlett, Kotrlik and Higgins (2001) and Krejcie and Morgan (1970) sampling determination. Out of 300 questionnaires, 234 were duly and accurately completed and returned, generating an adequate response rate of seventy-eight percent (78\%). Employees working in public service institutions provided an up-to-date, unexplored population for the set of variables of this study. A close-ended structured questionnaire derived and validated from the literature was used for data collection. Data were collected in public service institutions with the approval and consent from the authorities in each organization. As the study was designed to study human behavior, information about the respondents was kept confidential.

In the data-collection-instrument, 25 items of organizational citizenship behavior were used in previous studies and 21 items of organizational commitment were adopted from Rosario-Hernández and Millán (2004). According to Gliem and Gliem (2003), the Likert-scale is popular and widely used for measuring attitude and behavior. The Likert-scale is used in this study to measure attitude and behavior. As the instrument was modified to adjust it to the context of Chinese public service institutions, reliability of the instrument was tested, which turned out to be 0.82 , meeting the criteria of Brown (2002) and Gliem and Gliem, (2003). Collected data was analyzed through SPSS version 21.

\section{Results and discussion}

A keen observation was conducted on the personal characteristics of the people who participated in this study, as they could have an impact on organizational commitment and organizational citizenship. These personal characteristics were later used as controlled variables in analysis to avoid autogenic and endogenic biasness. To get a general idea, the descriptive statistics of this study are briefly summarized here. Sixty four per cent of the respondents were male, while thirty six per cent of the respondents were female. Gender has an influence on the variables of this study. Marital status was another important characteristic; the majority of the respondents (62\%) were married and the rest (38\%) were unmarried. Age is another important aspect which has a direct relationship with people's behavior at work. The majority of the correspondents (58\%) who participated in this study were between $30-40$ years old, followed by $40-50$ years old (32\%), 20-30 years old (6\%), and the last and smallest percentage was of those who were above 50 years old (3.8\%). The last two things of interest worth mentioning are educational level and experience level: the majority of the respondents (54\%) had bachelor degrees, followed by master's degree holders (29\%), postgraduate degree holders (13\%), while high school or below were just $2 \%$ of the whole sample set. Majority of the respondents have 5-10 years of experience in public service institutions, followed by respondents who have $10-15$ years of experience. 


\section{Correlation among variables}

A correlation test was conducted in order to examine the relationship and association between variables and constructs of this study. The correlation results gave us a general impression about the factors coefficients in this study. The results are presented in Table 1.

Table 1

Pearson Correlation Results

\begin{tabular}{|c|c|c|c|c|c|c|c|c|c|c|}
\hline & 1 & 2 & 3 & 4 & 5 & 6 & 7 & 8 & 9 & 10 \\
\hline $\begin{array}{l}\text { 1. Affective } \\
\text { Commitment }\end{array}$ & 1 & & & & & & & & & \\
\hline $\begin{array}{l}\text { 2. Normative } \\
\text { Commitment }\end{array}$ & $0.455^{\star *}$ & 1 & & & & & & & & \\
\hline $\begin{array}{l}\text { 3. Continuance } \\
\text { Commitment }\end{array}$ & $0.286^{* *}$ & $0.636^{* *}$ & 1 & & & & & & & \\
\hline $\begin{array}{l}\text { 4. Organizational } \\
\text { Commitment }\end{array}$ & $0.597^{\star *}$ & $0.798^{\star *}$ & $0.688^{* *}$ & 1 & & & & & & \\
\hline 5. Altruism & $0.292^{* *}$ & $0.694^{* *}$ & $0.719^{* *}$ & $0.640^{* *}$ & 1 & & & & & \\
\hline 6. Conscientiousness & $0.359^{* *}$ & $0.432^{\star *}$ & $0.464^{* *}$ & $0.488^{* *}$ & $0.534^{* *}$ & 1 & & & & \\
\hline 7. Sportsmanship & $0.380^{* *}$ & $0.360^{* *}$ & $0.387^{\star *}$ & $0.440^{* *}$ & $0.381^{* *}$ & $0.707^{* *}$ & 1 & & & \\
\hline 8. Courtesy & $0.791^{* *}$ & $0.292^{\star *}$ & $0.227^{\star *}$ & $0.464^{* *}$ & $0.232^{* *}$ & $0.341^{\star *}$ & $0.380^{* *}$ & 1 & & \\
\hline 9. Civic Virtue & $0.341^{\star *}$ & $0.417^{* *}$ & $0.483^{* *}$ & $0.472^{* *}$ & $0.361^{* *}$ & $0.548^{* *}$ & $0.507^{\star \star}$ & $0.274^{* *}$ & 1 & \\
\hline $\begin{array}{l}\text { 10. Organizational } \\
\text { Citizenship Behavior }\end{array}$ & $0.506^{\star \star}$ & $0.519^{\star *}$ & $0.542^{\star \star}$ & $0.629^{* *}$ & $0.551^{* *}$ & $0.770^{\star *}$ & $0.730^{* *}$ & $0.491^{\star *}$ & $0.631^{* *}$ & 1 \\
\hline
\end{tabular}

The correlation results revealed that there is a strong and positive association between variables. All the coefficients are positive, and all have significant associations. The focused variables for this study, organizational citizenship behavior and organizational commitment, were both positively and strongly associated with each other $(\mathrm{r}=0.629 ; \mathrm{p} \leq 0.01)$. H1 is accepted as it was proposed.

In principle, committed public sector employees will likely demonstrate the traits and desire of organizational citizenship behavior to improve the quality and image of public sector institutions. Such demonstrations from public sector employees means that everything is going well in public sector organizations. Public sector employees reveal and demonstrate these traits by assuming extra roles not defined in their job description, helping, assisting coworkers and customers, and strictly following the government rules and regulations, because of their emotional bond with their job and government setting. The results of this study are similar to studies done by Bogler and Somech, (2004) and Rifai (2005). However, we cannot generalize these results to all public sector employees due to different emotional and behavioral needs and wants. Due to different levels of commitment towards 
organizational goals and objectives among employees, organizational citizenship behavior of all employees cannot be the same. Nevertheless, the relationship between variables in this study turned out to be strong and positive, consistent with some previous studies (Cun, 2012; Moorman, 1991; Yen \& Niehoff, 2004; ZayasOrtiz et al., 2015).

\section{Regression analysis}

Regression analyses were done to find out the predicting power of $\mathrm{OC}$ in OCB. The existing literature indicates a connection between OC, OCB, and some of the employee characteristics. Therefore, these were controlled in Model 1, and organizational commitment is added to Model 2 as indicated in Table 2.

\section{Table 2}

\section{Regression Analysis}

\begin{tabular}{|l|c|c|}
\hline \multicolumn{1}{|c|}{ Control variables } & Model 1 $\boldsymbol{\beta}$ & Model 2 $\boldsymbol{\beta}$ \\
\hline Age & 0.073 & 0.028 \\
\hline Gender & -0.030 & 0.024 \\
\hline Marital status & -0.006 & -0.036 \\
\hline Educational level & -0.059 & -0.078 \\
\hline Experience & 0.031 & -0.023 \\
\hline Organizational commitment & & 0.805 \\
\hline $\mathrm{R}^{2}$ & 0.013 & 0.650 \\
\hline $\mathrm{R}^{2}$ (adj) & -0.009 & 0.640 \\
\hline$\Delta \mathrm{R}^{2}$ & 0.013 & 0.637 \\
\hline F change & 0.604 & 410.591 \\
\hline Significance (P-value) & 0.697 & 0.000 \\
\hline
\end{tabular}

The results obtained from regression analysis are statistically significant and support the stated hypothesis. The predictive power was considerably high since $\mathrm{R}^{2}=0.650$ with a significant value of $\mathrm{P}=0.00$. The standard error of the estimate was moderate at 0.325 . Although the control variables are not in the main scope of this study, finding them not significant raises scholarly interests, and shall be mentioned and recommended in the section for further study and recommendations. To support the findings and arguments of this study, other scholars like Shore and Wayne (1993) also indicated the association between organizational outcomes such as organizational citizenship behavior, performance and organizational commitment (effective and normative). Another study by Zayas-Ortiz et al. (2015) stated the positive association between the indicators of $\mathrm{OCB}$ and the dimensions of OC. Another study by Bogler and Somech (2004) on the connection among job satisfaction, OC, fairness perception and $\mathrm{OCB}$, indicated that only organizational commitment has predictive power in organizational citizenship behavior. 
The study by Chen and Francesco (2003) suggested a positive affiliation between affective commitment and OC while continuance commitment has a negative correlation with organizational citizenship behavior. Normative commitment was moderating the association between normative commitment and OCB. According to Fassina, Jones and Uggerslev (2008), having employees who demonstrate the traits of organizational citizenship behavior is vital for the survival of organizations now, due to globalization, customer orientation, and teambased approaches in work. Many scholars and researchers are focused on discovering ways of integrating organizational commitment in organizational practices to increase the organizational citizenship behavior level of their employees (Fassina et al., 2008).

The existing literature on organizational citizenship behavior indicates that OCB is the result of organizational and personal factors (İnce \& Gül, 2011). As the results of this study clearly indicate, people working in public service institutions have OCB tendencies, but there is not enough empirical evidence on the attendant predictors. Most studies on organizational citizenship behavior are conducted on the predicting power of OC in OCB (Gautam et al., 2005; Kim, 2006), especially studies conducted on OCB in Western countries (Farh et al., 2004). This study is not different from previous studies. Organizational commitment is a kind of psychological bond between the employee and his/ her organization based on normative pressure, to fulfil one's own duties and goals in order to stay loyal and effective (Lok \& Crawford, 2001). In the case of Chinese public service institutions, it is evident from anecdotal evidence that public servants will be less committed to go beyond what is in their job description. Nevertheless, organizational commitment has three categories, which are normative, effective and continuous commitment (Allen \& Meyer, 1990; Karim \& Noor, 2017). The relationship between organizational citizenship behavior and different dimensions of organizational commitment in developing countries needs more research and study, as most of the studies have been conducted in developed countries. (Farh et al., 2004). The debate about the relationship between OC and OCB (Alotaibi, 2001; Donglong et al., 2020; Gautam et al., 2005; Meyer, Stanley, Herscovitch \& Topolnytsky, 2002; Motalebi \& Marşap, 2020; Murphy, Athanasou \& King, 2002; Williams \& Anderson, 1991) has long been resolved from studies conducted recently. Scholarly studies have identified the predicting power of organizational commitment in OCB (Cohen, 2017; Dickinson, 2009; Feather \& Rauter, 2004; Gautam et al., 2005; Kehoe \& Wright, 2013). However, not enough studies have been conducted in the context of China. This study is built upon findings from studies conducted in Western countries. Despite the fact that organizational commitment is a huge predictor of organizational citizenship behavior, only a few governmental bodies have taken the initiative to incorporate it and create such an environment (Dessler \& Starke, 2004). The outcome of these studies is raising scholarly interest in the priorities of governmental organizations. Questions regarding governmental organizations practices such as leadership priorities and human resource practices need to be answered. The findings of this study are in line with those conducted in other countries, but various constructs predicting organizational citizenship 
behavior were not consistent. A series of further studies are needed to explore the grounded realities in the context of China as done by various researchers in extant literature.

\section{Conclusion and limitations}

This study is a part of the debate on organizational citizenship behavior and its predictors in the context of China. The findings of this study are consistent with previous studies (Dickinson, 2009; Feather \& Rauter, 2004; Gautam et al., 2005; Kehoe \& Wright, 2013; Motalebi \& Marşap, 2020). The findings of this study support previous studies, as the coefficient of determination is moderately high. This study provided an interesting insight into the role of personal characteristics used as control variables in the model. It is noteworthy that these personal factors were found not significant to predict OCB using human behavior in this study. In order to stay relevant and competitive, every organization should develop new approaches and techniques to measure and evaluate the performance of its human resources in order to manage them optimally. Organizations should incorporate those policies and practices that help develop attitudes and attributes required for fostering the noble conduct of organizational citizenship in human capital. The result of this study will enable us to enlighten the leadership of public sector organizations in devising the vision, mission, and strategy to choose those attributes and behaviors essential for staying relevant and competitive. People working in public service institutions are directly affecting the quality of life of a community, because public service institutions are part of the social structure that determines the standard of living. This study will provide guidance in conducting further research, devising policies and strategies. The findings of this study reveal that the policies for improving efficiency and productivity will work effectively, if they are nurtured in an environment that promotes organizational citizenship behavior. Policy makers should pay their utmost attention to the different aspects of organizational commitment (continuance, affective, and normative commitment) because of their implication for attitude and behavior. As has already been explained in this study, organizational citizenship behavior has different constructs, therefore, it wholly and solely depends upon the ability of practitioners to create an environment that promotes civic virtue, sportsmanship and courtesy. Organizational leadership should lead based upon the adaptation and implementation of such policies. This study found important research gaps for future studies. The high predicting power of organizational commitment in Chinese public service institutions is raising scholarly interest and it should be further investigated in the context of Chinese private sector organizations to see if it gives us the same results or not. The controlled variables (age, gender, experience, educational level, marital status) used in this study are found to be not that significant but deserve further scholarly attention.

In the context of practical implementation of OCB, the results of this study clearly support the idea that policy makers of public service institutions should focus more on building organizational citizenship behavior by investing in organizational commitment. The nurturing of organizational citizenship behavior 
among public servants through organizational commitment will not only improve the effectiveness of public sector employees, but also promote good governance in public service institutions.

There were a few challenges and limitations in conducting this study. The foremost challenge was the Chinese organizational setting in which this study was conducted. Because of the unique Chinese characteristics inherited by institutions in China, this research may not have contextualized the true spirit of this study in the Chinese context. The questionnaires used in this study for data collection may not have conveyed the exact concepts as they were translated from English into Chinese. The lack of literature in the Chinese specific context was another limitation for this study to elaborate discussion. This study was conducted in public service institutions of Hefei city; therefore, generalizability of this study is limited. The use of a quantitative approach might not be sufficient to discover the reasons behind employee attitude and behavior; qualitative input will be very helpful in digging out the true reasons behind employee attitudes and behaviors. Lastly, the statistical tool used in this study to analyze the variables is very simple in nature and not as sophisticated as some scholars might wish. However, this study is believed to be a focal point for future studies in the context of Chinese institutions.

\section{REFERENCES}

1. Allen, N.J. \& Meyer, J.P. (1990). The Measurement and Antecedents of Affective, Continuance and Normative Commitment to the Organization. Journal of Occupational and Organizational Psychology, vol. 63, no 1, pp. 1-18.

2. Alotaibi, A.G. (2001). Antecedents of Organizational Citizenship Behavior: A Study of Public Personnel in Kuwait. Public Personnel Management, vol. 30, no 3, pp. 363-376.

3. Barlett, J.E., Kotrlik, J.W. \& Higgins, C.C. (2001). Organizational Research: Determining Appropriate Sample Size in Survey Research. Information Technology, Learning, and Performance Journal, vol. 19, no 1, pp. 43.

4. Becker, H.S. (1960). Notes on the Concept of Commitment. American Journal of Sociology, vol. 66, no 1, pp. 32-40.

5. Becker, T.E. (1992). Foci and Bases of Commitment: Are They Distinctions Worth Making? Academy of Management Journal, vol. 35, no 1, pp. 232-244.

6. Bodla, A.A., Tang, N., Van Dick, R. \& Mir, U.R. (2019). Authoritarian Leadership, Organizational Citizenship Behavior, and Organizational Deviance. Leadership \& Organization Development Journal.

7. Bogler, R. \& Somech, A. (2004). Influence of Teacher Empowerment on Teachers' Organizational Commitment, Professional Commitment and Organizational Citizenship Behavior in Schools. Teaching and Teacher Education, vol. 20, no 3, pp. 277-289. 
8. Brown, J.D. (2002). The Cronbach Alpha Reliability Estimate. JALT Testing \& Evaluation SIG Newsletter, vol. 6, no 1.

9. Chen, Z.X. \& Francesco, A.M. (2000). Employee Demography, Organizational Commitment, and Turnover Intentions in China: Do Cultural Differences Matter? Human Relations, vol. 53, no 6, pp. 869-887. Available at: https://doi.org/10.1177/0018726700536005 (accessed: 17 December 2020).

10. Chen, Z. X. \& Francesco, A. M. (2003). The Relationship Between the Three Components of Commitment and Employee Performance in China. Journal of Vocational Behavior, vol. 62, no 3, pp. 490-510.

11. Chen, Z.X., Tsui, A.S. \& Farh, J. (2002). Loyalty to Supervisor vs. Organizational Commitment: Relationships to Employee Performance in China. Journal of Occupational and Organizational Psychology, vol. 75, no 3, pp. 339-356.

12. Clugston, M., Howell, J.P. \& Dorfman, P.W. (2000). Dispositional Influences on Pay Preferences. Journal of Business and Psychology, vol. 15, no 2, pp. 311-320.

13. Cohen, A. (2017). Organizational Commitment and Turnover: A Meta-Analysis. Academy of Management Journal.

14. Cun, X. (2012). Public Service Motivation and Job Satisfaction, Organizational Citizenship Behavior. Chinese Management Studies, vol. 6, no 2, pp. 330-340. Available at: https://doi. org/10.1108/17506141211236758 (accessed: 17 December 2020).

15. Davenport, T.O. (1999). Human Capital: Employees Want a Return on Their Investment, and They Expect Managers to Help Them Get It. Management Review, vol. 88, no 11, pp. 37.

16. Dessler, G. \& Starke, F.A. (2004). Management: Principles and Practices for Tomorrow's Leaders. Pearson/Prentice Hall.

17. Dickinson, L. (2009). An Examination of the Factors Affecting Organizational Citizenship Behavior. University of Tennessee At Chattanooga, Accounting and Finance.

18. Donglong, Z., Taejun, C., Julie, A. \& Sanghun, L. (2020). The Structural Relationship Between Organizational Justice and Organizational Citizenship Behavior in University Faculty in China: The Mediating Effect of Organizational Commitment. Asia Pacific Education Review, vol. 21, no 1, pp. 167-179.

19. Ensher, E.A., Grant-Vallone, E.J. \& Donaldson, S.I. (2001). Effects of Perceived Discrimation on Job Satisfaction, Organizational Commitment, Organizational Citizenship Behavior, And Grievances. Human Resource Development Quarterly, vol. 12, no 1, pp. 53.

20. Farh, J.-L.L., Zhong, C.-B. \& Organ, D.W. (2004). Organizational Citizenship Behavior in the People's Republic of China. Organization Science, vol. 15, no 2, pp. 241-253.

21. Fassina, N.E., Jones, D.A. \& Uggerslev, K.L. (2008). Meta-Analytic Tests of Relationships between Organizational Justice and Citizenship Behavior: Testing Agent-System and SharedVariance Models. Journal of Organizational Behavior, vol. 29, no 6, pp. 805-828.

22. Feather, N.T. \& Rauter, K.A. (2004). Organizational Citizenship Behaviours in Relation to Job Status, Job Insecurity, Organizational Commitment and Identification, Job Satisfaction and Work Values. Journal of Occupational and Organizational Psychology, vol. 77, no 1, pp. 81-94.

23. Gautam, T., Van Dick, R., Wagner, U., Upadhyay, N. \& Davis, A.J. (2005). Organizational Citizenship Behavior and Organizational Commitment in Nepal. Asian Journal of Social Psychology, vol. 8, no 3, pp. 305-314. 
24. Gliem, J.A. \& Gliem, R.R. (2003). Calculating, Interpreting, and Reporting Cronbach's Alpha Reliability Coefficient for Likert-Type Scales. Midwest Research-to-Practice Conference in Adult, Continuing, and Community Education.

25. Hallberg, U.E. \& Schaufeli, W. B. (2006). "Same Same” But Different? Can Work Engagement Be Discriminated from Job Involvement and Organizational Commitment? European Psychologist, vol. 11, no 2, pp. 119-127.

26. Hui, C., Law, K.S. \& Chen, Z.X. (1999). A Structural Equation Model of the Effects of Negative Affectivity, Leader-Member Exchange, and Perceived Job Mobility on in-Role and Extra-Role Performance: A Chinese Case. Organizational Behavior and Human Decision Processes, vol. 77, no 1, pp. 3-21.

27. Huselid, M.A. (1995). The Impact of Human Resource Management Practices on Turnover, Productivity, and Corporate Financial Performance. Academy of Management Journal, vol. 38, no 3, pp. 635-672.

28. İnce, M. \& Gül, H. (2011). The Effect of Employees' Perceptions of Organizational Justice on Organizational Citizenship Behavior: An Application in Turkish Public Institutions. International Journal of Business and Management, vol. 6, no 6, p. 134.

29. Jung, H.-S., Park, J.-R. \& Yoon, H.-H. (2010). The Effects of Employees' Emotional Intelligence upon Organizational Citizenship Behavior and Job Performance in the Foodservice Industry. Culinary Science and Hospitality Research, no 16.

30. Karim, N.H.A. \& Noor, N.H.N.M. (2017). Evaluating the Psychometric Properties of Allen and Meyer's Organizational Commitment Scale: A Cross Cultural Application among Malaysian Academic Librarians. Malaysian Journal of Library \& Information Science, vol. 11, no 1, pp. 89-101.

31. Kehoe, R.R. \& Wright, P.M. (2013). The Impact of High-Performance Human Resource Practices on Employees' Attitudes and Behaviors. Journal of Management, vol. 39, no 2, pp. 366-391.

32. Khan, M.A., Ismail, F.B., Hussain, A. \& Alghazali, B. (2020). The Interplay of Leadership Styles, Innovative Work Behavior, Organizational Culture, and Organizational Citizenship Behavior. SAGE Open, vol. 10, no 1, 2158244019898264.

33. Kim, S. (2006). Public Service Motivation and Organizational Citizenship Behavior in Korea. International Journal of Manpower, vol. 27, no 8, pp. 722-740.

34. Krejcie, R.V \& Morgan, D.W. (1970). Determining Sample Size for Research Activities. Educational and Psychological Measurement, vol. 30, no 3, pp. 607-610.

35. Lambert, E.G., Keena, L.D., Leone, M., May, D. \& Haynes, S.H. (2020). The Effects of Distributive and Procedural Justice on Job Satisfaction and Organizational Commitment of Correctional Staff. The Social Science Journal, pp. 1-12.

36. Loi, R., Hang-Yue, N. \& Foley, S. (2006). Linking Employees' Justice Perceptions to Organizational Commitment and Intention to Leave: The Mediating Role of Perceived Organizational Support. Journal of Occupational and Organizational Psychology, vol. 79, no 1, pp. 101-120.

37. Lok, P. \& Crawford, J. (2001). Antecedents of Organizational Commitment and the Mediating Role of Job Satisfaction. Journal of Managerial Psychology, vol. 16, no 8, pp. 594-613. Available at: https://doi.org/10.1108/EUM0000000006302 (accessed: 17 December 2020). 
38. Mathieu, J.E. \& Zajac, D.M. (1990). A Review and Meta-Analysis of the Antecedents, Correlates, and Consequences of Organizational Commitment. Psychological Bulletin, vol. 108, no 2, pp. 171.

39. Meyer, J.P. (1997). Organizational Commitment. International Review of Industrial and Organizational Psychology, no 12, pp. 175-228.

40. Meyer, J.P. \& Allen, N.J. (1991). A Three-Component Conceptualization of Organizational Commitment. Human Resource Management Review, vol. 1, no 1, pp. 61-89.

41. Meyer, J.P., Becker, T.E. \& Vandenberghe, C. (2004). Employee Commitment and Motivation: A Conceptual Analysis and Integrative Model. Journal of Applied Psychology, vol. 89, no 6, pp. 991.

42. Meyer, J.P., Stanley, D.J., Herscovitch, L. \& Topolnytsky, L. (2002). Affective, Continuance, And Normative Commitment to the Organization: A Meta-Analysis of Antecedents, Correlates, and Consequences. Journal of Vocational Behavior, vol. 61, no 1, pp. 20-52.

43. Meynhardt, T., Brieger, S.A. \& Hermann, C. (2020). Organizational Public Value and Employee Life Satisfaction: The Mediating Roles of Work Engagement and Organizational Citizenship Behavior. The International Journal of Human Resource Management, vol. 31, no 12, pp. 1560-1593.

44. Moorman, R.H. (1991). Relationship between Organizational Justice And Organizational Citizenship Behaviors: Do Fairness Perceptions Influence Employee Citizenship? Journal Of Applied Psychology, 76(6), 845.

45. Moorman, R. H., Niehoff, B. P. \& Organ, D. W. (1993). Treating Employees Fairly and Organizational Citizenship Behavior: Sorting the Effects of Job Satisfaction, Organizational Commitment, and Procedural Justice. Employee Responsibilities and Rights Journal, vol. 6, no 3, pp. 209-225.

46. Motalebi, P. \& Marşap, A. (2020). The Role of Job Satisfaction, and Organizational Commitment as a Determinant of Organizational Citizenship Behavior among the Workers of Welfare Organization. SSRG International Journal of Economics and Management Studies (SSRG-IJEMS), vol. 7, no 1, pp. 102-112.

47. Motowidlo, S.J. (2000). Some Basic Issues Related to Contextual Performance and Organizational Citizenship Behavior in Human Resource Management. Human Resource Management Review, vol. 10, no 1, pp.115-126.

48. Muchinsky, P.M.P.M. (2007). Psicología Aplicada al Trabajo.

49. Murphy, G., Athanasou, J. \& King, N. (2002). Job Satisfaction and Organizational Citizenship Behaviour: A Study of Australian Human-Service Professionals. Journal of Managerial Psychology, vol. 17, no 4, pp. 287-297.

50. Newstrom, J.W. \& Davis, K. (1986). Human Behavior at Work. New York, NY.

51. Nguni, S., Sleegers, P. \& Denessen, E. (2006). Transformational and Transactional Leadership Effects on Teachers' Job Satisfaction, Organizational Commitment, and Organizational Citizenship Behavior in Primary Schools: The Tanzanian Case. School Effectiveness and School Improvement, vol. 17, no 2, pp. 145-177.

52. Organ, D.W. (1988). Organizational Citizenship Behavior: The Good Soldier Syndrome. Lexington Books/DC Heath and Com. 
53. Organ, D.W. (1997). Organizational Citizenship Behavior: It's Construct Clean-Up Time. Human Performance, vol. 10, no 2, pp. 85-97.

54. Organ, D.W. \& Ryan, K. (1995). A Meta-Analytic Review of Attitudinal and Dispositional Predictors of Organizational Citizenship Behavior. Personnel Psychology, vol. 48, no 4, pp. $775-802$.

55. Osborne, D. \& Gaebler, T. (1993). Reinventing Government: The Five Strategies for Reinventing Government. New York: Penguin.

56. Pattanayak, B. (2020). Human Resource Management. PHI Learning Pvt. Ltd.

57. Podsakoff, P.M., Mackenzie, S.B., Paine, J.B. \& Bachrach, D.G. (2000). Organizational Citizenship Behaviors: A Critical Review of the Theoretical and Empirical Literature and Suggestions for Future Research. Journal of Management, vol. 26, no 3, pp. 513-563.

58. Rifai, H.A. (2005). A Test of the Relationships Among Perceptions of Justice, Job Satisfaction, Affective Commitment and Organizational Citizenship Behavior. Gadjah Mada International Journal of Business, vol. 7, no 2.

59. Rosario-Hernández, E. \& Millán, L. (2004). Development and Validation of Organizational Citizenship Scale. Puerto Rican Journal of Psychology, vol. 15, no 1, pp. 1-25.

60. Shin, N., Park, S.H. \& Park, S. (2019). Partnership-Based Supply Chain Collaboration: Impact on Commitment, Innovation, and Firm Performance. Sustainability, vol. 11, no 2, p. 449.

61. Shore, L.M. \& Wayne, S.J. (1993). Commitment and Employee Behavior: Comparison of Affective Commitment and Continuance Commitment with Perceived Organizational Support. Journal of Applied Psychology, vol. 78, no 5, p. 774.

62. Smith, C.A., Organ, D.W. \& Near, J.P. (1983). Organizational Citizenship Behavior: Its Nature and Antecedents. Journal of Applied Psychology, vol. 68, no 4, p. 653.

63. Wagner, S.L. \& Rush, M.C. (2000). Altruistic Organizational Citizenship Behavior: Context, Disposition, and Age. The Journal of Social Psychology, vol. 140, no 3, pp. 379-391.

64. Wasti, S.A. (2003). Organizational Commitment, Turnover Intentions and the Influence of Cultural Values. Journal of Occupational and Organizational Psychology, vol. 76, no 3, pp. 303-321.

65. Williams, L.J. \& Anderson, S.E. (1991). Job Satisfaction and Organizational Commitment as Predictors of Organizational Citizenship and In-Role Behaviors. Journal of Management, vol. 17, no 3, pp. 601-617.

66. Yen, H.R. \& Niehoff, B.P. (2004). Organizational Citizenship Behaviors and Organizational Effectiveness: Examining Relationships in Taiwanese Banks. Journal of Applied Social Psychology, vol. 34, no 8, pp. 1617-1637.

67. Zayas-Ortiz, M., Rosario, E., Marquez, E. \& Colón Gruñeiro, P. (2015). Relationship between Organizational Commitments and Organizational Citizenship Behaviour. In: A Sample of Private Banking Employees. International Journal of Sociology and Social Policy, vol. 35, no 1/2, pp. 91-106. Available at: https://doi.org/10.1108/IJSSP-02-2014-0010 (accessed: 17 December 2020). 